\title{
The Effect of Customer Equity Drivers on Word-of-Mouth Behavior with Mediating Role of Customer Loyalty and Purchase Intention
}

\author{
Mohammad Reza Karimi Alavijeh ${ }^{1}$, Ahmad Esmaeili ${ }^{2}$, Akbar Sepahvand ${ }^{3}$, Vida Davidaviciene ${ }^{4}$ \\ ${ }^{1,2,3}$ Allameh Tabataba'i University \\ Dehkadeh-ye-Olympic, Teheran, Iran \\ E-mail.mr.karimi@atu.ac.ir, Ahmet.ismaeili@gmail.com,a.sepahvand1991@gmail.com \\ ${ }^{4}$ Vilnius Gediminas Technical University \\ Sauletekio al. 11, LT-10223, Vilnius, Lithuania \\ E-mail.vida.davidaviciene@vgtu.lt
}

cross $^{r e f}$ http://dx.doi.org/10.5755/j01.ee.29.2.17718

\begin{abstract}
The uncertain stand in terms of product and service quality invites customers to get the advantage of other customers' experiences in order to make a purchase decision. It has been discussed that word-of-mouth (WOM) influences consumer purchase behavior and it could create a robust tie like relatives and could also tie as close friends, acquaintances, and strangers. This paper intends to define the concepts of WOM and customer equity and study the terminology of current purchase intention, customer loyalty and correlates to consumer decision making. The data were collected utilizing selfadministrated questionnaires. The results are obtained using Smart PLS 2.0, then using the bootstrap algorithm the tstatistics are analyzed. The results indicate that customer equity drivers increase the customer loyalty and consequently ends in WOM by the customers. Despite the literature which has investigated the influence of customer equity drivers on the loyalty and purchase intention of the customers, this study contributes the analysis of drivers on WOM. Also, it reveals that if a firm invests in the customer equity drivers, the result will be loyalty and accordingly, the easiest way of advertisement that would be WOM. This study only focuses on a unique industry that can impact the generalizability of the contexts. Also, it relates only to the positive WOM effects. Future studies could strengthen the literature by taking in negative WOM with a broader population.
\end{abstract}

Keywords: Word-of-Mouth; Brand Equity; Value Equity; Relationship Equity; Purchase Intention.

\section{Introduction}

Word-of-mouth (WOM) is one of the most important processes in communication to influence attitudes and behaviors in customers (Chevalier \& Mayzlin, 2006). The uncertain stand in terms of product and service quality invites customers to get the advantage of other customers' experiences to make a purchase decision (Mudambi \& Schuff, 2010). Also, companies view WOM as a highly relevant, credible and persuasive option; which involves customer-to-customer communication; compared to classic actions in marketing (Trusov et al., 2009). Add to this, the online communication options which allow rapid and accessible online reviews of the customers which indicate the importance of WOM. Arndt (1967) defines WOM as a face-to-face interaction between customers regarding services, products or brands. WOM can be traced to be the oldest form of marketing communication and existed much before printing press and radio. There exists a definitive literature on offline WOM. It has been discussed that WOM influences consumer purchase behavior and it could create a robust tie like relative and could also tie as close friends, acquaintances, and strangers (Duhan et al., 1997; Granovetter, 1973, 1983; Steffes \& Burgee, 2009). Recently it has been discussed that customer equity effects WOM (Kuo et al, 2012).
Customer equity is a vital factor which guarantees a firm's success in the long run and is the antecedent of the firm's long-term values (Kim, Park, Kim, Aiello, \& Donvito, 2012). The term can be thought of as the whole value of a firm's customers, both current and potential, in its discounted lifetime (Rust, Zeithaml, \& Lemon, 2004). Regarding both current and potential customers, as a mathematical model (Rust et al., 2004) and a conceptual framework (Rust et al., 2000), customer equity vital as mentioned. In terms of economic concepts, the evaluation of the marketing effectiveness is the analysis of the amount returned on the investment in marketing activities. On the other hand, the conceptual framework uses three elements that result in the creation and growth of customer equity: value, brand, and relationship equity.

As such, value equity is the evaluation that a consumer makes between the trade-off of what is paid and what is received (Rust et al., 2000; Zeithaml, 1988). Brand equity is the value associated with the name of the brand (Farquhar, 1989) and the effect of the brand knowledge on how the consumer's response to the marketing of the brand (Keller, 1993). Relationship equity is defined as how willing the consumers are to buy one particular brand because they have benefitted from the brand (Lemon, Rust \& Zeithaml, 2001; Rust et al., 2000; Roy, Khandeparkar, and Motiani 2016; Arikan, Yilmaz \& Bodur 2016; Moreira, Fortes \& Santiago 2017; Hajli et al., 2017; Voyer, Kastanakis \& Rhode 2017). 
In order to explain how the customer equity construct impacts consumers' behavioral outcomes, the major focus of this study is on the conceptual framework and the aforementioned three drivers of customer equity.

Last but not least is the increasingly competitive nature of the markets that have forced firms to pay unprecedented attention to the matter of loyal customers, especially how to attain them and increase their value and their incentive to buy their brands (Watson et al., 2015). In this paper, these two variables (Customer loyalty and Purchase intention) have been considered as mediating variables. Hence, the purpose of this paper is to examine the effect of customer equity drivers of customer loyalty and current purchase and WOM behavior.

In this paper, the concepts of WOM and customer equity will be defined and then the terminology of current purchase intention, customer loyalty and correlates of the consumer decision-making process are presented. Based on the literature the constructs will be presented an integrated conceptual framework.

\section{Customer Equity Drivers - Impact of Customer Equity Drivers on Customer Loyalty}

Blattberg et al. (2001) claim that clients are the untouchable assets that a firm should cleverly increase, keep, and win them just like other financial properties. The most determinant of the long-living values of the firm has been thought to be equity, which is usually defined as the discounted sum of customer lifetime values (Kim et al., 2010; Lemon et al., 2001). Customer equity concentrates on gaining lifetime value of a positive customer and identifies customer value to the selling firm. Blattberg \& Deighton (1996) for the first time suggested the customer equity concept. During the last decade, many marketing scholars (Reinartz \& Kumar, 2000; Blattberg et al., 2001; Rust et al., 2000, 2004; Ramaseshan, Rabbanee \& Tan Hsin Hui 2013; Lee et al., 2014; Zhang, van Doorn \& Leeflang 2014; Yoon \& Oh 2016; Godey et al., 2016; Segarra-Moliner \& Moliner-Tena 2016; Wang et al., 2016) expanded and revised the concept of customer equity. Rust et al. (2000) provided customer equity model to measure customers as a market-based asset, which was one of the first methods developed and correlated it with the performance of firms. In this line, in the present literature, many other important models have been suggested. For example, Bolton et al. (2004) used CLV to measure financial results of the firm, and linked marketing inputs to financial results, the behavior of the customer and customer realization. Verhoef (2003) connected relationship marketing and customer relationship realization to the behavior of the customer. To assess customer lifetime value (CLV), Reinartz \& Kumar (2000) and Rust et al. (2004) used CLV to measure firm's financial outcomes and suggested various models (Ramaseshan et al., 2013).

In Lemon et al. (2001), relationship, brand, and value are three kinds of equity, as important drivers of general customer equity. First, "equity of relationship" shows the likelihood of customers to exceed subjective and objective evaluation of a brand, and keep in touch with it. Furthermore, far away and above the customer's subjective and objective evaluation of the service/good, equity of relationship is the customers' aptness to go near to the company (mentally) and stay with it (Zhang et al., 2014). On one hand, because different alternatives are given to customers, loyalty to a definite brand does not grow very much in comparison to the past. On the other hand, loyalty programs in the control of a company might expand equity of relationship. Building strong customer relationship by special appreciation or treatment is very important. Also, to improve relationship equity, community programs can act as an efficient way (Kim et al., 2011).

Second, equity of a brand is a customer's untouchable and subjective evaluation of the brand which is far away from its value (Kim et al., 2008; Lemon et al., 2001). Building profiles that make customers to differentiate that uniqueness from others is a brand's profession. Corporate ethics, viewpoint around the brand, and awareness of brand are the important actionable keys of brand equity.

Third, the customer's objective assessment of the utility of a brand is known as "equity of value" and it is based on the viewpoints that when one gives something, what he gets in turn? (Vogel et al., 2008). It involves the customers' objective evaluation of the utility of a service /good, which is based on the idea that what they receive compared to what they give up (Rust et al., 2004). Convenience, price, and quality are three key focuses on equity of value (Lemon et al., 2001).

In many companies, loyalty has been evaluated and researched. In order to produce strong relationships with customers, it is important to make strategies aimed at loyalty, because loyalty can make a lot of benefits, such as reduced operational costs, increased sales, and reduced marketing costs (Hao Zhang et al., 2010). Composite measurements, attitudinal measurements, and behavioral measurements are commonly three different methods to evaluate loyalty. Although both attitudinal measurements and behavioral measurements cannot exactly measure loyalty, the first method mixes the two other dimensions and measures loyalty in both behavioral and attitudinal ways. Usually, two dimensions are included in this approach, in which one dimension will buy certain product/service again and the other will suggest it to others. In earlier studies, this two-dimensional measurement approach has been used (e.g., Day, 1969; Taylor et al., 2003; Vogel et al., 2008; Ko et al., 2009; Hao Zhang et al., 2010; Akrout et al., 2016). Thus, in order to measure loyalty of the customer, this study also uses the composite method.

Vogel et al. (2008) suggested that customers' loyalty intentions (attitudinal) are positively affected by drivers of customer equity. Early research suggests that all three drivers of customer equity connect positively with loyalty goals (e.g., Vogel et al., 2008; Zhang et al., 2014). A loyalty program (LP) is one of the most important means in the management of customer equity. In order to increase customers' loyalty and expand firms' benefit, it is a longliving marketing tool that rewards customers who buy on frequent occasions (Zhanga et al., 2010). Under LPs, by the collection of LP points, member customers are permitted to the allocation of LP points for future buys, or by the saving of LP points, they are permitted to discounts on present buys (Ho Hwang et al., 2016). On the contrary, drivers of customer equity (CED's) (relationship equity, brand equity, and value equity) are customer loyalty goals' determinants (Rust et al., 2004; Zhang et al., 2014). 
Customers seem to select a brand that has a positive and appreciative profile. Keller (1993) said that customers will have positive brand equity meaning when they connect with a specific brand, and in that case, they react more to the brand's marketing activities. Bolton et al. (2004) found that affective commitment is positively influenced by the enthusiastic view of a brand. Ko et al. (2009) showed that one of the most important drivers of customer loyalty can be thought as equity of the brand. Rust et al. (2000) said that brand equity seems to impact a customer's desire to suggest a brand, stay, and rebuy the brand. Therefore, we believe that:

H1. Brand equity has a positive impact on loyalty.

Some scholars have claimed that customer loyalty is highly affected by relationship value (Ismail, 2015; Zhang, 2016). Value is the key factor to analyze the relationship of customers with a given firm. If a firm's services and/or products don't satisfy the customer's expectations and needs, even the best marketing strategies, relationship management, and brand management will not be enough (Ramaseshan et al., 2013). Rust et al. (2004) stated that a customer's switching tendency is affected by value equity, a measure of a customer loyalty. Possibly because of consumers' higher value-for-money attitudes, equity of value is more important for their loyalty (Bao et al., 2003). Furthermore, as Adams (1965) put in the equity theory, the sensed equity yields positive emotional situations, such as loyalty, trust, and satisfaction, which bring on positive attitudes. Therefore:

H3. Value equity has a positive impact on loyalty.

In order to keep customers, value equity and great brand equity are not enough. To absorb the customers, further the firms must invest in the equity of relationship (Richards \& Jones, 2008). There is a high change from items to services and from transactions to relationships in this economic competition; therefore, equity of relationship is very important, especially when the benefits attained in terms of cash value is less than the value of the loyalty programs of the firm. This could yield a spark for the firms to invest in the long-term relationship by getting to know the strong desire of the customers in the upcoming purchases. (Ramaseshan et al., 2013). Raimondo et al. (2008) found that relational equity, in highly competitive and clear situations, is a consistent determinant of customer loyalty and that its effect increases together with the age of the relationship. Therefore, it is expected that:

H5. Relationship equity has a positive impact on loyalty.

\section{Customer Equity Drivers' Influence on Purchase Intention}

An individual's goal to buy a service or a product is purchase intention and a purchase intention may finally cause actual purchase (Follows \& Jobber, 2000). A mix of consumers' possibility and desire in buying a product is contributed as purchase intention. Many studies suggest that purchase intention highly connects to desire and viewpoint toward a product or a brand (Kim et al., 2010; Kim \& Ko 2010; Zhang, van Doorn \& Leeflang 2014; Arikan, Yilmaz \& Bodur 2016; Christou 2015; Hajli et al., 2017; Lee et al., 2014; Moreira, Fortes \& Santiago 2017; Roy, Khandeparkar \& Motiani 2016; Voyer, Kastanakis \& Rhode 2017).
Customer equity is a behavioral variable which represents real purchasing record, and purchase intention is an attitudinal variable which measures future contributions of customers to a brand. Customers' future behavior should be estimated more promptly because it seems to become an important concern for a firm (Park et al., 2010).

Predicting future customer behavior necessarily requires the ways of matching their actions and attitudes. Attitude is prior to behavior. Many research dealing with decision-making processes have proved this idea. Therefore, customer equity drivers seem to have similar impacts on purchase intention too (Kim \& Ko, 2012).To analyze customer equity, Holehonnur et al. (2009), based on their literature, created a conceptual framework. They used Zeithaml's study (1988) to recognize value equity drivers, realize the effect of brand equity on decision-making processes, and to understand the influence of value equity on consumers' decision-making process.

Holehonnur et al. (2009) have shown that there is a relation between purchase intentions and value equity. They clarified that the intention to behave minds to behavior and that purchase intention are mostly based on a consumer's objective evaluation (equity of value). Therefore, the outcome was that when the consumer's value equity increases, the consumer's purchase intention will increase. In addition, their research clarified that as purchase intentions are evaluated as consumer's subjective assessment (brand equity), brand equity is linked to purchase intentions. Therefore, they discovered that purchase intention will increase if consumer's brand equity increases. Vogel et al. (2008, p.100) in their research have proved that between purchase intentions and relationship equity, there is a positive relation. They described that customers feel more familiar with the employees of the store, brand and the store in the case that perceived relationship equity increases. Regarding many past studies, such as Thorsten et al. (2002) and Patterson \& Smith (2001), there is a strong relationship between loyalty, satisfaction, and relationship equity. This will increase the customer's intention to buy a particular service or product.

Kosarizadeh \& Hamdi (2015) suggested that value equity, a comparative factor in comparison with other trademarks, is an essential factor in the intention of consumers purchase. Furthermore, the level of communication equity of firms which produce leather is decreased and increased the equity of value. Consumers' desire to buy, raises or reduces. In other words, increasing the rate of consumers' communication equity could result in their desired expansion for purchase. Finally, it is concluded that an effective factor on the purchase intention of leather product consumers, in the society under research, is brand equity. Therefore, following hypotheses are expected:

$\mathbf{H}_{2}$. Brand equity has a positive impact on purchase intention.

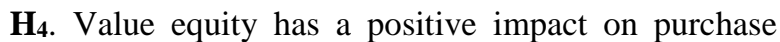
intention.

H6. Relationship equity has a positive impact on purchase intention. 


\section{Purchase Intention and Customer Loyalty Influence on WOM Behaviors}

The WOM literature has focused on customer dissatisfaction and complaint behavior. The customer's belief that he or she will discuss an event, not directly linked to the service difficulty, with another person is considered as WOM intentions (Swanson \& Davis, 2003). WOM contributes to individual evaluations of organizations, services, brands, or products that are spread out in face to face or other communication channels in every part of social networks or made without any commercial intention (Kuo et al., 2012). WOM is seen more dependable and valid than messages from marketers or advertisers (Carl, 2006). Much like rebuy, positive WOM is a behavioral intention but it deals with the intention to suggest (Berry et al., 1994). Because people talk about their good experiences with services and products to co-workers, friends, family, and others, which impacts other possible customers to buy, and firm profitability results from positive WOM (Lori, 2008).

Lately, not only the increase of the internet has raised the breadth and speed of information spread, but it also excited more consumers to so and so share their ideas about a service or product. These ideas are derived from personal experiences. Such feedbacks, whether negative or positive, are used by consumers as important resources when making purchase decisions and are seen as more trustworthy than suggestions from product or service providers. As a result, consumer after-purchase impression and purchase are highly affected by WOM (Kuo et al., 2012).

Many researchers have stated that the WOM behavior of customers positively affects purchase intention (Wirtz \& Chew, 2002; Banyte et al., 2014; Davidaviciene \& Davidavicius 2014; Li et al., 2014; Skackauskiene et al., 2015). The WOM behavior of consumers is positively influenced by the present purchase intention (Christina, 2008). When a new service or product is suggested to others, it causes a consumer to wish for benefits for her/himself, which may result from an expansive spread of the service, e.g. a lower price by lower total production costs because of much production. On the contrary, a consumer's uncertainty with respect to her/his cognitive tension linked with a buy may be reduced by extensive spread of a service or product (Christina, 2008). On the other hand, many types of research in the literature show that positive WOM and rebuy would be positively connected to each other (Lori, 2008). Hence, we expect that:

H7. Purchase intention has a positive impact on WOM behavior.

"An intention to conduct a different set of behaviors that suggest an enthusiasm in keeping a relationship with the central firm" is defined as loyalty, which includes frequent buying, connecting to WOM, and devoting a higher share of the category wallet to the particular service provider (Sirdeshmukh et al., 2002). Dick \& Basu (1994) trying to clarify the relationship between WOM and loyalty, claimed that it is more likely for a loyal customer to reveal a positive WOM. This is rooted in the proposed connection of loyalty and WOM behavior. Later on, de Matos \& Rossi (2008) through a meta-analysis indicated that loyal customers to a service provider, provide positive suggestions to other source groups. On the contrary, disloyal customers spread negative WOM on the firm. Past study supported loyalty's impact on WOM intention, then it can be said that after service recovery from failures, WOM intention will be positively affected by customer loyalty (Choi \& Choi, 2014). In addition, behavioral results of customer loyalty were examined by Gremler (1995). She discovered that positive WOM is one of the outcomes resulting from loyalty; it means that people how much admire or suggest the company. Srinivasan et al. (2002) confirm this finding. On the other hand, Kumar et al. (2003) complete that WOM as a result of loyalty. Therefore, following hypothesis are stated based on the above discussions:

H8. Loyalty has a positive impact on WOM behavior.

Figure 1 models the relationships between customer equity drivers, purchase intention, loyalty, and WOM.

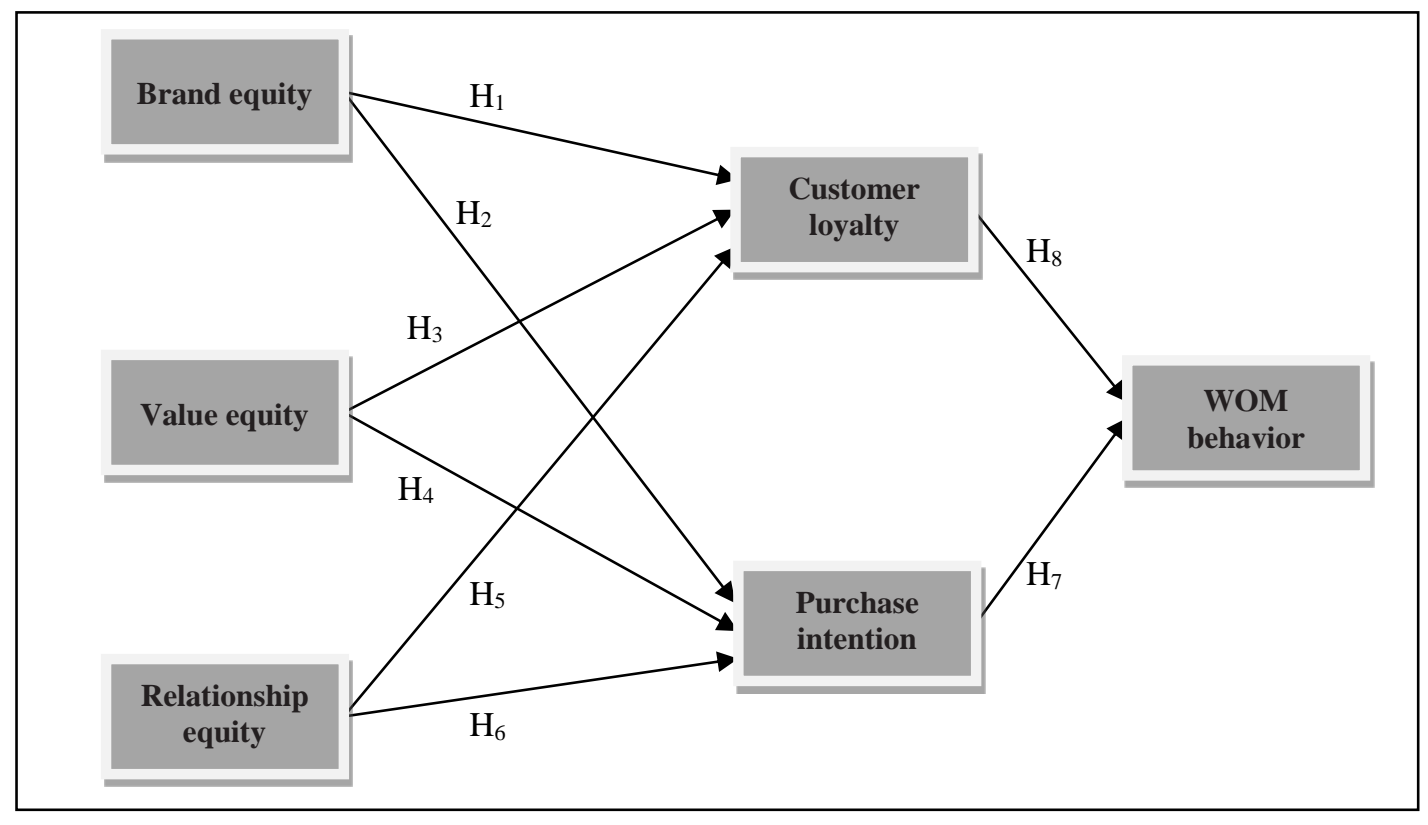

Figure 1. Research Model Based on the Developed Hypothesis 


\section{Methodology}

This study is practical in purpose and in terms of the method can be considered as correlational descriptive. The research procedure includes a review of the literature and the data required to test the hypotheses were collected using self-administered questionnaires. Each question refers to a previous study represented in Table 1. The research participants are customers of Bank X in Tehran. The initial phase of questionnaire development was in English. Then through back translation, it was translated to Persian to better involve the participants in the questions. The questionnaire was distributed to 10 customers, including experts, to check the understandability of the items. Using feedbacks the items were refined or were rephrased.
Cronbach's alpha test was carried out to test the reliability of the questionnaire. The results show that the alpha value is 0.878 , which is an indication of high reliability. The results are obtained using Smart PLS 2.0 relying on the discussion of Ringle et al., (2005).

\section{Measurement Model}

On the reliability of the measurement tool, the Cronbach's $\alpha$ for the constructs are higher than 0.7 (See Table 1). Based on Nunnally (1978) the values suggest a strong reliability. Also, the composite reliability values meet the criterion suggested by Chin \& Gopal (1995) (All of which are higher than 0.8).

Latent Variables' Statistics

Table 1

\begin{tabular}{|c|c|c|c|c|c|c|}
\hline Construct & Items & Reference & $\begin{array}{c}\text { Loading } \\
\text { value }\end{array}$ & Cronbach's $\alpha$ & $\mathbf{C R}$ & AVE \\
\hline \multirow{4}{*}{$\begin{array}{l}\text { Brand } \\
\text { Equity }\end{array}$} & BE 1: This brand is a strong brand. & \multirow{4}{*}{ Chae et al. (2015) } & 0.853 & \multirow{4}{*}{0.861} & \multirow{4}{*}{0.905} & \multirow{4}{*}{0.706} \\
\hline & BE 2: This brand is an attractive brand. & & 0.844 & & & \\
\hline & BE 3: This brand is a unique brand. & & 0.849 & & & \\
\hline & BE 4: This brand is a likable brand. & & 0.814 & & & \\
\hline \multirow[b]{2}{*}{ Loyalty } & LO 1: I will repurchase this brand. & \multirow[b]{2}{*}{ Zhang et al. (2012) } & 0.892 & \multirow[b]{2}{*}{0.716} & \multirow[b]{2}{*}{0.875} & \multirow[b]{2}{*}{0.778} \\
\hline & $\begin{array}{l}\text { LO 2: I will recommend this brand to other } \\
\text { people. }\end{array}$ & & 0.871 & & & \\
\hline \multirow{3}{*}{$\begin{array}{l}\text { Purchase } \\
\text { Intention }\end{array}$} & PI 1: I would repurchase this brand. & \multirow{3}{*}{$\begin{array}{l}\text { Hong et al. (2012), } \\
\text { Sichtmann (2007) }\end{array}$} & 0.860 & \multirow{3}{*}{0.763} & \multirow{3}{*}{0.861} & \multirow{3}{*}{0.675} \\
\hline & $\begin{array}{l}\text { PI 2: I would consider purchasing from this brand } \\
\text { in the next three months. }\end{array}$ & & 0.785 & & & \\
\hline & PI 3: For this purchase, I will buy from this brand. & & 0.817 & & & \\
\hline \multirow{3}{*}{$\begin{array}{l}\text { Relationship } \\
\text { Equity }\end{array}$} & $\begin{array}{l}\text { RE 1: I have multiple purchase experiences with } \\
\text { this brand. }\end{array}$ & \multirow{3}{*}{ Zhang et al. (2012) } & 0.879 & \multirow{3}{*}{0.856} & \multirow{3}{*}{0.912} & \multirow{3}{*}{0.776} \\
\hline & RE 2: I always visit this brand. & & 0.882 & & & \\
\hline & RE 3: I have a special feeling for this brand. & & 0.882 & & & \\
\hline \multirow{3}{*}{ Value Equity } & VE 1: The product of this brand is very attractive. & \multirow{3}{*}{ Zhang et al. (2012) } & 0.905 & \multirow{3}{*}{0.895} & \multirow{3}{*}{0.934} & \multirow{3}{*}{0.826} \\
\hline & VE 2: The competitiveness of the price is good. & & 0.903 & & & \\
\hline & VE 3: Owning this product is a status symbol. & & 0.918 & & & \\
\hline \multirow{3}{*}{ WOM } & $\begin{array}{l}\text { WOM 1: I would tell other people positive things } \\
\text { about this brand. }\end{array}$ & \multirow{3}{*}{$\begin{array}{l}\text { Chae et al. (2015), } \\
\text { Sichtmann (2007) }\end{array}$} & 0.749 & \multirow{3}{*}{0.717} & \multirow{3}{*}{0.838} & \multirow{3}{*}{0.635} \\
\hline & $\begin{array}{l}\text { WOM 2: I would recommend this brand to other } \\
\text { people. }\end{array}$ & & 0.849 & & & \\
\hline & $\begin{array}{l}\text { WOM 3: I would provide my friends, family, and } \\
\text { neighbors with positive things about this brand } \\
\text { when deciding to choose a brand. }\end{array}$ & & 0.788 & & & \\
\hline
\end{tabular}

Utilizing reliability test, the convergent and divergent validity was tested. For each of the items, the loading values are higher than 0.7. As Fornell \& Larcker (1981) suggested the average variance extracted must be above 0.6 , which in this study the criterion is met (Table 1).

For the latent variables, all the AVE values are in line with the criterion of discriminant validity suggested by Fornell \& Larcker (1981) (Table 2.).

\section{Structural Model Analysis}

Using bootstrap algorithm, the t-statistics are analyzed. For each of the hypotheses, the value of t-statistics above 1.96 , approves the relation of the constructs and accordingly confirms the research hypotheses at $95 \%$ confidence level. (The significance values in $99 \%$ and $99.9 \%$ levels of confidence are 2.58 and 3.27 , respectively). Figure 2 presents the results of the bootstrap algorithm.

\section{Correlation of Constructs and AVE}

\begin{tabular}{|c|c|c|c|c|c|c|}
\hline & BE & CUL & PUI & RE & VE & WOMb \\
\hline BE & 1.000 & & & & & \\
\hline CUL & 0.592 & 1.000 & & & & \\
\hline PUI & 0.484 & 0.421 & 1.000 & & & \\
\hline RE & 0.599 & 0.570 & 0.494 & 1.000 & & \\
\hline VE & 0.695 & 0.666 & 0.515 & 0.613 & 1.000 & \\
\hline WOMb & 0.581 & 0.510 & 0.321 & 0.478 & 0.489 & 1.000 \\
\hline
\end{tabular}




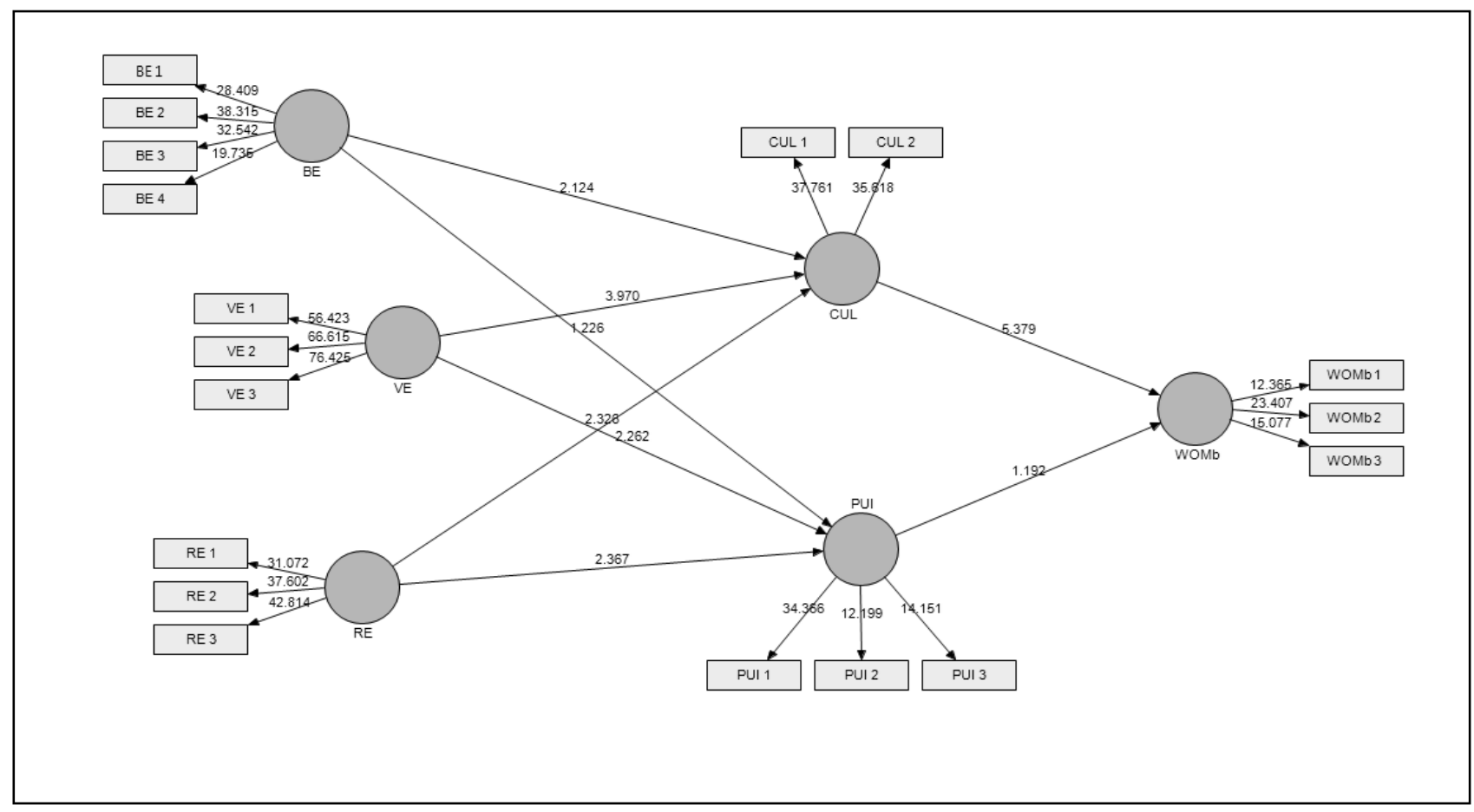

Figure 2. T-Statistic Using Bootstrap Algorithm

To calculate the standard path coefficients of constructs the PLS algorithm is utilized. Standardized coefficients reveal that to what extent the dependent variables are being explained by independent variables. Figure 3 presents the standardized coefficients for the hypothesis.

Table 3 presents the hypothesis testing results. If $\mathrm{P}$ value is under 0.05 or the value of t-statistics is outside the range of 1.96 to -1.96 the hypothesis is supported, else the hypothesis will not be supported. The results indicate that Brand Equity has a positive impact on Loyalty $\left(\mathrm{H}_{1}\right)$. The positive effect of Brand Equity on Purchase Intention is not supported. Also, the results indicate that Value Equity has a positive impact on both loyalty and purchase intention.

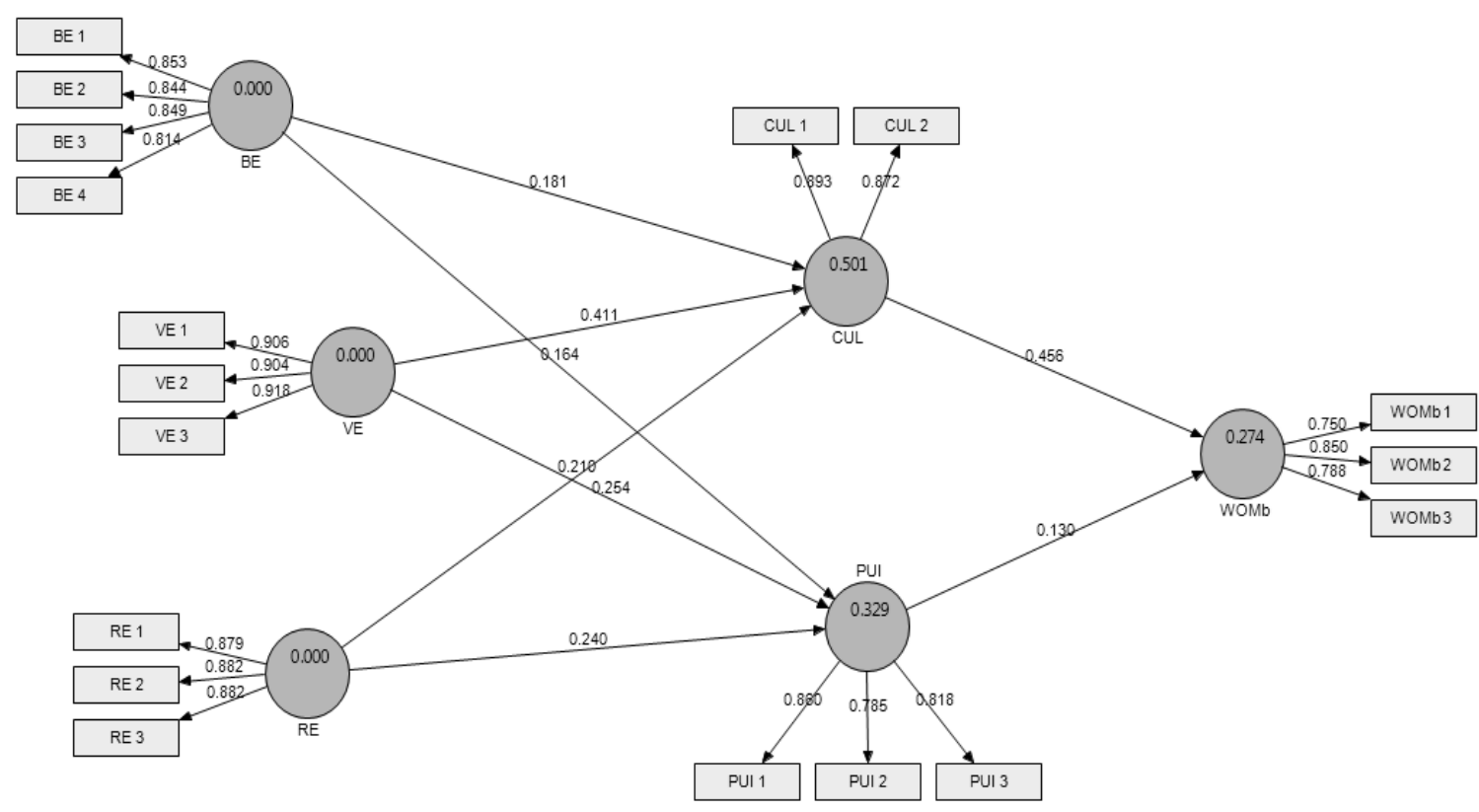

Figure 3. The Standardized Coefficients for the Hypothesis 
The Correlation between Variables

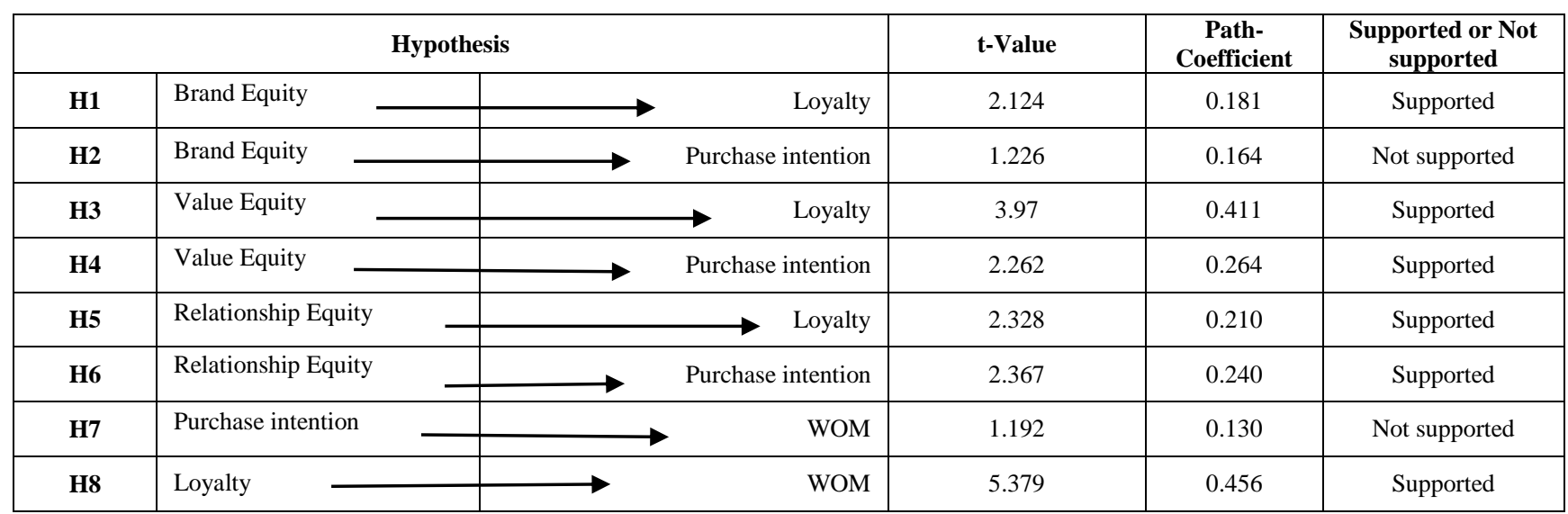

$* \mathrm{P}<0.05 ; * * \mathrm{P}<0.01 ; * * * \mathrm{P}<0.001$

\section{Mediating Effect of Variables}

To test the indirect effect of a third variable (Loyalty, Purchase Intention), the relation of the third variable must be meaningful for both first (Brand Equity) and second (WOM) variable. Since the only mediating variable (Loyalty) that's relation is meaningful with both dependent and independent variables, the indirect effect of the Loyalty can be tested. For Purchase Intention as a mediator, since the direct effect of Brand Equity and WOM is not supported, the mediating effect cannot be analyzed. In addition, the path coefficient of an indirect effect is the result of multiplying two direct effects on the mediating variable. The results indicate that Loyalty acts as a mediator $(\mathrm{P}<0.05)$ between Brand Equity and WOM.

The Results on Mediating effect of Variables

\begin{tabular}{|c|c|c|c|c|c|c|}
\hline Dependent Variable & & Mediator & & Independent Variable & Indirect Effect Value & $\begin{array}{c}\text { Supported or Not } \\
\text { Supported }\end{array}$ \\
\hline Brand Equity & $\rightarrow$ & Loyalty & - & WOM & 0.082 & Supported \\
\hline Value Equity & $\rightarrow$ & Loyalty & - & $\longrightarrow$ & 0.187 & Supported \\
\hline Relationship Equity & \begin{tabular}{l|l} 
& $\rightarrow$ \\
\end{tabular} & Loyalty & - & $\longrightarrow$ & 0.096 & Supported \\
\hline
\end{tabular}

\section{Discussion}

Customer-centrism is a necessity for a firm to prosper. The theoretical framework for a firm to develop toward customers is customer equity models. This study investigated the literature on the subject based on three customer equity drivers: relationship equity, value equity, and brand equity. We have analyzed survey data to investigate the effect of these three drivers on customer loyalty and customer purchase intention.

The results indicate that customer loyalty is being positively affected by three drivers and accordingly customers' loyalty has a positive influence on the purchase intention of customers. The results are in accordance with Lemon et al. (2001) and Chae et al. (2015). Also, Vogel et al. (2008) indicated that equity theory describes that brand equity displays positive circumstances, maintaining a positive attitude toward a brand that enhances satisfaction and loyalty. Customers sense a traditional value as a result of relationship equity and brand equity. In the other words, when the experiences and the expectations are compared to the customers and they sense that they have been treated better than other customers, it is more likely for them to be satisfied and become loyal to the brand and all the offerings.

The analysis of the structural model reveals that the dimensions of value equity and relationship equity positively influence purchase intention. These results confirm the results obtained by Kim \& Ko (2012). They further assert that to predict customer future behavior, one must match the attitudes and actions of the customers. This seems the direct results of the positive influence of the value equity (attitude toward brand) and relationship equity (actions) on purchase intention (customer future behavior).

This study also suggests that the strongest predictor of purchase intention is valued equity, as in luxury fashion brands. Johnson et al. (2006) assert that over time, the effect of brand equity on behavioral intentions increases whereas the effect of value equity decreases. This result can be traced to the fact that banking industry customers are more concerned with the value offered by the bank.

Casidy \& Wymer (2015) found that customer loyalty directly effects WOM. The results obtained in the current study suggests the same. Also, value equity, relationship equity, and brand equity indirectly influence WOM. There is an inter-construct relation between loyalty and equity drivers. In other words, loyalty is influenced by equity drivers and in turn, loyalty acts as a mediator between equity drivers and positive WOM. One must account the fact that equity drivers are influenced by WOM (behavior marketing activities) which is an increase in value, brand, and relationship. Since the effect of brand value on purchase intention is not supported, the mediating role of purchase intention within the relation of equity drivers and WOM cannot be analyzed. 


\section{Conclusions}

This study intended to analyze the customer equity drivers. To analyze the effect of customer equity drivers on WOM considering the mediating role of loyalty and purchase intention. The results indicate that customer equity drivers increase the customer loyalty and consequently ends in WOM by the customers. Despite the literature which has investigated the influence of customer equity drivers on the loyalty and purchase intention of the customers, this study contributes the analysis of drivers on WOM. Also, it reveals that if a firm invests in the customer equity drivers, the result will be loyalty and accordingly, the easiest way of advertisement that would be WOM. In other words, if an organization could generate a special value and create a valuable brand for the customers, one can expect that WOM throughout customers. On the other words, the results obtained in this study indicate that the purchase intention of the customers is not affected by WOM which can be traced to the local cultural values in Iran.

If the bank administration highlights the importance of brand value equity and develops the relationship with customers through service customization, customer needs a diagnosis, proper brand positioning, and offering proper value, the result will be the loyalty of the customers. It is important also to consider that the long-term relationship with promotion offerings can alter the attitude of the customers and end in WOM. The WOM not only presents good opportunities in the traditional sense of advertisement but also on the newly developed electronic world, which is regarded as more efficient and fruitful.

The value discussed above can be maintained through high service quality, higher levels of product quality, price, and the convenience firms offer. All the customers are not alike and don't like to be treated so. This is an important issue for the managers that homogeneous contacts with customers are not favorable due to the misrepresentation of the value equity and constant loyal relationship with customers that can be flawed. It should be noted that value equity varies over industries, varies over the maturity of the firms and the customer decision-making processes. Managers should note that various dimensions of value affect the loyalty if the resources are not distributed evenly within the customer segments. It is crucial to understand that brands can manage customer equity drivers and managers must understand the portfolio of value equity, brand equity, and relationship management. This will increase the customer loyalty to the brands. Businesses have to specify a section for the customer participation in terms of invites to increase customers' WOM and engagement. This entails the plans to provoke customer participation in services and brands to increase the equity and loyalty of the customers. The result will be the justification to decide on the service dimensions to be intensified and reinforced in the marketing sections and strategies.

This study signifies the importance of concepts that has been little researched. But still, some limitations must be noted to broaden the landscape of the future researchers. This study only focuses on a unique industry that can impact the generalizability of the contexts. Crosby et al. (1990) noted that if the services provided by the firms are complex and can be customized over time, the interpersonal relationship between firms and customers gain significance. So the results must contextually generalize. This means that the contexts of the firms acting must be duly and properly noted. Also, this study considers certain concepts and variables that beside focus and positive contributions has its flaws. Future studies could examine the influence of other important variables like commitment and trust on the equity drivers and customer loyalty.

Another limitation of this study relates to the positive WOM effects that we have considered. Future studies could focus on the negative aspects of WOM influenced by the customer equity drivers and loyalty. If it is true that WOM is influenced positively, why it can't be negatively influenced?

The role of the non-members in the customer sections of a firm could also be analyzed. Comparisons can be made between members and non-members of the various customer segments, who take a role in the known WOM patterns and E-WOM patterns. This insight could pave the way to set activities to influence non-members, too. Future studies also can be directed to examine the social networks and brand communities within those social networks.

\section{References}

Adams, J. S. (1966). Inequity in Social Exchange. Advances in Experimental Social Psychology, 2(C), $267-299$. https://doi.org/10.1016/S0065-2601(08)60108-2

Akrout, H., Diallo, M. F., Akrout, W., \& Chandon, J. L. (2016). Affective trust in buyer-seller relationships : a two-dimensional scale. Journal of Business \& Industrial Marketing, 31(2), 260-273. https://doi.org/10.1108/JBIM-11-2014-0223

Arikan, E., Yilmaz, C., \& Bodur, M. (2016). Expanding the boundary of brand extensions through brand relationship quality. Journal of Business Economics and Management, 17(6), 930-944. https://doi.org/10.3846/16111699.2016.1220420

Arndt, J. (1967). Role of Product-Related Conversations in the Diffusion of a New Product. Journal of Marketing Research, 4(3), 291. https://doi.org/10.2307/3149462

Banyte, J., Tarute, A., \& Taujanskyte, A. (2014). Customer Engagement into Value Creation: Determining Factors and Relations with Loyalty. Inzinerine Ekonomika-Engineering Economics, 25(5), 568-77. Available from internet: http://www.inzeko.ktu.lt/index.php/EE/article/view/8402 (March 6, 2017). http://dx.doi.org/10.5755/j01.ee.25.5.8402

Berry, L. L., Parasuraman, A., \& Zeithaml, V. a. (1994). Improving service quality in America: Lessons learned. Academy of Management Executive, 8(2), 32-45. https://doi.org/10.5465/AME.1994.9503101072

Blattberg, R. C., \& Deighton, J. (1996). Manage marketing by the customer equity test. Harvard Business Review, 74(4), 136144. https://doi.org/10.1142/9789814287067_0013 
Blattberg, R. C., Getz, G., \& Thomas, J. S. (2001), Customer Equity: Building and Managing Relationships as Valuable Assets, Harvard Business School Press, Boston, MA.

Bolton, R. N., Lemon, K. N., \& Verhoef, P. C. (2004). The Theoretical Underpinnings of Customer Asset Management: A Framework and Propositions for Future Research. Journal of the Academy of Marketing Science, 32(3), $271-292$. https://doi.org/10.1177/0092070304263341

Casidy, R., \& Wymer, W. (2015). The impact of brand strength on satisfaction, loyalty and WOM: An empirical examination in the higher education sector. Journal of Brand Management, 22(2), 117-135. Article. https://doi.org/10.1057/bm.2015.6

Chae, H., Ko, E., \& Han, J. (2015). How do customers' SNS participation activities impact on customer equity drivers and customer loyalty? Focus on the SNS services of a global SPA brand. Journal of Global Scholars of Marketing Science, 25(2), 122-141. JOUR. https://doi.org/10.1080/21639159.2015.1012809

Chevalier, J. A., \& Mayzlin, D. (2006). The Effect of Word of Mouth on Sales: Online Book Reviews. Journal of Marketing Research, 43(3), 345-354. https://doi.org/10.1509/jmkr.43.3.345

Chin, W. W., \& Gopal, A. (1995). Adoption intention in GSS. ACM SIGMIS Database, 26(2-3), 42-64. https://doi.org/10.114 $5 / 217278.217285$

Choi, B., \& Choi, B. J. (2014). The effects of perceived service recovery justice on customer affection, loyalty, and word-ofmouth. European Journal of Marketing, 48(1/2), 108-131. https://doi.org/10.1108/EJM-06-2011-0299

Christou, E. (2015). Branding Social Media in the Travel Industry. Procedia - Social and Behavioral Sciences, 175, $607-614$. https://doi.org/http://dx.doi.org/10.1016/j.sbspro.2015.01.1244

Crosby, L. A., Evans, K. R., \& Cowles, D. (1990). Relationship Quality in Services Selling: An Interpersonal Influence Perspective. Journal of Marketing, 54(July), 68-81. https://doi.org/http://dx.doi.org.ezproxy.cityu.edu.hk/10.23 $07 / 1251817$

Davidaviciene, V., \& Davidavicius, S. (2014). Social Networks in Marketing Communication - Case of Lithuania. Scientific bulletin of National Mining University 4(142), 101-7.

Day, G. S. (1969). A Two-Dimensional Concept of Brand Loyalty. Journal of Advertising Research, 9(3), 29-35. https://doi.org/10.2307/3150565

de Matos, C. A., \& Rossi, C. A. V. (2008). Word-of-mouth communications in marketing: a meta-analytic review of the antecedents and moderators. Journal of the Academy of Marketing Science, 36(4), 578-596. https://doi.org/10.1007 /s11747-008-0121-1

Deepak, S., Jagdip, S., \& Sabol, B. (2002). Consumer Trust, Value, and Loyalty in Relational Exchanges. Journal of Marketing, 66(1), 15-37. https://doi.org/10.1509/jmkg.66.1.15.18449

Dick, A. S., \& Basu, K. (1994). Customer Loyalty: Toward an Integrated Conceptual Framework. Journal of the Academy of Marketing Science, 22(2), 99-113. https://doi.org/10.1177/0092070394222001

Duhan, D. F., Johnson, S. D., Wilcox, J. B., \& Harrell, G. D. (1997). Influences on Consumer Use of Word-of-Mouth Recommendation Sources. Journal of the Academy of Marketing Science, 25(4), 283-295. https://doi.org/10.117 7/0092070397254001

Farquhar, P. H. (1989). Managing Brand Equity. Marketing Research. https://doi.org/10.2307/1252048

Follows, S. B., \& Jobber, D. (2000). Environmentally responsible purchase behavior: a test of a consumer model. European Journal of Marketing, 34(5/6), 723-746. https://doi.org/10.1108/03090560010322009

Fornell, C., \& Larcker, D. F. (1981). Evaluations structural equation models with unobservable variables and measurement error. Journal of Marketing Research, 18(1), 39-50. https://doi.org/10.2307/3151312

Godey, B., Manthiou, A., Pederzoli, D., Rokka, J., Aiello, G., Donvito, R., \& Singh, R. (2016). Social media marketing efforts of luxury brands: Influence on brand equity and consumer behavior. Journal of Business Research, 69(12), 5833-5841. https://doi.org/http://dx.doi.org/10.1016/j.jbusres.2016.04.181

Granovetter, M. S. (1973). The strength of weak ties. American Journal of Sociology, 78(6), 1360-1380. https://doi.org/10.1086/225469

Gremler, D. D. (1995). The effect of satisfaction, switching costs, and interpersonal bonds on service loyalty. Unpublished doctoral dissertation, Arizona State University, Tucson, Arizona.

Hajli, N., Shanmugam, M., Papagiannidis, S., Zahay, D., \& Richard, M. O. (2017). Branding co-creation with members of online brand communities. Journal of Business Research, 70, 136-144. https://doi.org/http://dx.doi.org/10. 1016/j.jbusres.2016.08.026

Holehonnur, A., Raymond, M. A., Hopkins, C. D., \& Fine, A. C. (2009). Examining the customer equity framework from a consumer perspective. Journal of Brand Management, 17(3), 165-180. Article. https://doi.org/10.1057/bm.2009.21

Hwang, J. H., Chung, J., Kim, J. W., Lee, D., \& Yoo, W. S. (2016). Antecedents to loyalty point redemption: Implications for customer equity management. Journal of Business Research, 69(9), 3731-3739. JOUR. https://doi.org/http://dx.d oi.org/10. 1016/j.jbusres.2015.12.065 
Mohammad Reza Karimi Alavijeh, Ahmad Esmaeili, Akbar Sepahvand, Vida Davidaviciene. The Effect of Customer...

Ismail, A. R. (2015). Leveraging the potential of word of mouth: The role of love, excitement and image of fashion brands. Journal of Global Fashion Marketing, 6(2), 87-102. JOUR. https://doi.org/10.1080/20932685.2014.999013

Johnson, M. D., Herrmann, A., \& Huber, F. (2006). The Evolution of Loyalty Intentions. Journal of Marketing, 70(2), 122132. https://doi.org/10.1509/jmkg.70.2.122

Keller, K. L. (1993). Conceptualizing, measuring, and managing customer-based brand equity. Journal of Marketing, 57(1), 1. https://doi.org/10.2307/1252054

Kim, A. J., \& Ko, E. (2012). Do social media marketing activities enhance customer equity? An empirical study of luxury fashion brand. Journal of Business Research, 65(10), 1480-1486. https://doi.org/10.1016/j.jbusres.2011.10.014

Kim, J., Kim, J. E., \& Johnson, K. K. P. (2010). The Customer-salesperson Relationship and Sales Effectiveness in Luxury Fashion Stores: The Role of Self-Monitoring. Journal of Global Fashion Marketing, 1(4), 230-239. https://doi.org/10.1080/20932685.2010.10593074

Kim, Kyung H., Ko, Eunju J., Hooley, Graham J., Lee, Nick J., Lee, DongHae, Jung, Hong-Seob, Jeon, Byung J., Moon, Hakil \& Hoon, Kim K. (2008). Brand equity and purchase intention in fashion industry:a cross-cultural study in Asia and Europe. Journal of Global Academy of Marketing Science, 18 (4), pp. 247-278.

Kim, N., Park, J., Kim, K. H., Aiello, G., \& Donvito, R. (2012). A Study on Measuring and Defining Customer Equity of Complex Shopping Malls. Journal of Global Fashion Marketing, 3(2), 71-80. JOUR. https://doi.org/10.1080/209 32685.2012.10593109

Ko, E., Kim, K. H., Kim, S. H., Li, G., Zou, P., \& Zhang, H. (2009). The Relationship among Country of Origin, Brand Equity and Brand Loyalty: Comparison among USA, China and Korea. Journal of Global Academy of Marketing Science, 19(1), 47-58. JOUR. https://doi.org/10.1080/12297119.2009.9707286

Kosarizadeh, M., \& Hamdi, K. (2015). Studying the Effect of Social Media on Consumer Purchase Intention (Case Study: Leather Products). J. Appl. Environ. Biol. Sci, 5(7), 171-181.

Kumar, V., Bohling, T. R., \& Ladda, R. N. (2003). Antecedents and consequences of relationship intention: Implications for transaction and relationship marketing. Industrial Marketing Management, 32(8), 667-676. https://doi.org/10.1016 /j.indmarman.2003.06.007

Lee, C. H., Ko, E., Tikkanen, H., Phan, M. C. T., Aiello, G., Donvito, R., \& Raithel, S. (2014). Marketing mix and customer equity of $\{\mathrm{SPA}\}$ brands:Cross-cultural perspectives. Journal of Business Research, 67(10), $2155-2163$. https://doi.org/http://dx.doi.org/10.1016/j.jbusres.2014.04.025

Lemon, K., Rust, R., \& Zeithaml, V. (2001). What drives customer equity? Marketing Management, 10, $20-25$. https://doi.org/10.1016/j.tiv.2010.07.023

Li, H., Song, W., \& Collins, R. (2014). Post-event visits as the sources of marketing strategy sustainability: a conceptual model approach. Journal of Business Economics and Management, 15(1), 74-95. https://doi.org/10.3846/16111699.20 12.701229

Moreira, A. C., Fortes, N., \& Santiago, R. (2017). Influence of sensory stimuli on brand experience, brand equity and purchase intention. Journal of Business Economics and Management, 18(1), 68-83. https://doi.org/10.3846/1611 1699.2016.1252793

Mudambi, S., \& Schuff, D. (2010). What Makes a Helpful Online Review? A Study of Customer Reviews on Amazon.com. MIS Quarterly, 34(1), 185-200. Retrieved from http://aisel.aisnet.org/cgi/viewcontent.cgi?article=2898\&context=misq. https://doi.org/10.2307/20721420

Nunnally, J. C. (1978). Psychometric theory (2nd ed.). New York, NY: McGraw-Hill.

Ramaseshan, B., Rabbanee, F. K., \& Tan Hsin Hui, L. (2013). Effects of customer equity drivers on customer loyalty in B2B context. Journal of Business \& Industrial Marketing, 28(4), 335-346. https://doi.org/10.1108/08858621311313929

Ramaseshan, B., Rabbanee, F. K., \& Tan Hsin Hui, L. (2013). Effects of customer equity drivers on customer loyalty in B2B context. Journal of Business \& Industrial Marketing, 28(4), 335-346. https://doi.org/10.1108/08858621311313929

Reinartz, W., \& Kumar, V. (2000). On the Profitability of Long-Life Customers in a No contractual Setting: An Empirical Investigation and Implications for Marketing. Journal of Marketing, 64(4), 17-35. Retrieved from http://www.jstor.o $\mathrm{rg} / \mathrm{stable} / 3203475$

Richards, K. A., \& Jones, E. (2008). Customer relationship management: Finding value drivers. Industrial Marketing Management, 37(2), 120-130. https://doi.org/10.1016/j.indmarman.2006.08.005

Ringle, C. M., Sarstedt, M., \& Mooi, E. A. 2010. "Response-Based Segmentation Using Finite Mixture Partial Least Squares: Theoretical Foundations and an Application to American Customer Satisfaction Index Data," Annals of Information Systems (8), pp. 19-49

Roy, P., Khandeparkar, K., \& Motiani, M. (2016). A lovable personality: The effect of brand personality on brand love. Journal of Brand Management, 23(5), 97-113. https://doi.org/10.1057/s41262-016-0005-5

Rust, R. T., Lemon, K. N., \& Zeithaml, V. A. (2004). Return on Marketing: Using Customer Equity to Focus Marketing Strategy. Journal of Marketing, 68(1), 109-127. JOUR. https://doi.org/10.1509/jmkg.68.1.109.24030 
Rust, R. T., Zeithaml, V. A., \& Lemon, K. N. (2000), Driving Customer Equity: How Customer Lifetime Value Is Reshaping Corporate Strategy, The Free Press, New York, NY.

Segarra-Moliner, J. R., \& Moliner-Tena, M. A. (2016). Customer equity and $\{$ CLV $\}$ in Spanish telecommunication services. Journal of Business Research, 69(10), 4694-4705. https://doi.org/http://dx.doi.org/10.1016/j.jbusres.2016.04.017

Skackauskiene, I., Vilkaite-Vaitone, N., Raudeliuniene, J., \& Davidaviciene, V. (2016). A model for measuring passenger loyalty. Transport, 31(1), 100-107. https://doi.org/10.3846/16484142.2015.1094748

Srinivasan, S. S., Anderson, R., \& Ponnavolu, K. (2002). Customer loyalty in e-commerce: An exploration of its antecedents and consequences. Journal of Retailing, 78(1), 41-50. https://doi.org/10.1016/S0022-4359(01)00065-3

Steffes, E. M., \& Burgee, L. E. (2009). Social ties and online word of mouth. Internet Research, 19(1), 42-59. https://doi.org/10.1108/10662240910927812

Swanson, S. R., \& Davis, J. C. (2003). The relationship of differential loci with perceived quality and behavioral intentions. Journal of Services Marketing, 17(2), 202-219. JOUR. https://doi.org/10.1108/08876040310467943

Taylor, C. R., Kim, K. H., Kim, D. Y., \& Moon, H. IL. (2002). Antecedents of Brand Loyalty in South Korean Rice Market. Journal of Global Academy of Marketing Science, 9(1), 175-188. JOUR. https://doi.org/10.1080/1229711 9.2002.9707314

Trusov, M., Bucklin, R. E., \& Pauwels, K. (2009). Effects of Word-of-Mouth versus Traditional Marketing: Findings from an Internet Social Networking Site. Journal of Marketing, 73(5), 90-102. https://doi.org/10.1509/jmkg.73.5.90

Verhoef, P. C. (2003). Understanding the effect of customer relationship management efforts on customer retention and customer share development. Journal of Marketing, 67(4), 30-45. https://doi.org/10.1509/jmkg.67.4.30.18685

Vogel, V., Evanschitzky, H., \& Ramaseshan, B. (2008). Customer Equity Drivers and Future Sales. Customer Equity Drivers and Future Sales, 72(6), 98-108. https://doi.org/10.1509/jmkg.72.6.98

Voyer, B. G., Kastanakis, M. N., \& Rhode, A. K. (2017). Co-creating stakeholder and brand identities: A cross-cultural consumer perspective. Journal of Business Research, 70, 399-410. https://doi.org/http://dx.doi.org/10.10 16/j.jbusres.2016.07.010

Wang, H., Kim, K. H., Ko, E., \& Liu, H. (2016). Relationship between service quality and customer equity in traditional markets. Journal of Business Research, 69(9), 3827-3834. https://doi.org/http://dx.doi.org/10.1016/j.jbusres.2016.04.007

Watson, G. F., Beck, J. T., Henderson, C. M., \& Palmatier, R. W. (2015). Building, measuring, and profiting from customer loyalty. Journal of the Academy of Marketing Science, 43(6), 790-825. https://doi.org/10.1007/s11747-015-0439-4

Wirtz, J., \& Chew, P. (2002). The effects of incentives, deal proneness, satisfaction and tie strength on word-of-mouth behavior. International Journal of Service Industry Management, 13(2), 141-162. https://doi.org/10.1108/09564230210425340

Ying-Feng, K., Tzu-Li, H., \& Shu-Chen, Y. (2013). Effects of inertia and satisfaction in female online shoppers on repeatpurchase intention: The moderating roles of word-of-mouth and alternative attraction. Managing Service Quality: An International Journal, 23(3), 168-187. https://doi.org/10.1108/09604521311312219

Yoon, S., \& Oh, J. C. (2016). A cross-national validation of a new retail customer equity model. International Journal of Consumer Studies, 40(6), 652-664. https://doi.org/10.1111/ijcs.12289

Zeithaml, V. A. (1998). Consumer perceptions of price, quality, and value: a means-end model and synthesis of evidence. Journal of Marketing, 52(3), 2-22. https://doi.org/10.2307/1251446

Zhang, H., Ko, E., \& Kim, K. H. (2010). The Influences of Customer Equity Drivers on Customer Equity and Loyalty in the Sports Shoe Industry: Comparing Korea and China. Journal of Global Fashion Marketing, 1(2), 110-118. https://doi.org/10.1080/20932685.2010.10593063

Zhang, R., Li, G., Wang, Z., \& Wang, H. (2016). Relationship value based on customer equity influences on online groupbuying customer loyalty. Journal of Business Research, 69(9), 3820-3826. https://doi.org/10.1016/j.jbusres.2015.12.074

Zhang, S., van Doorn, J., \& Leeflang, P. S. H. (2014). Does the importance of value, brand and relationship equity for customer loyalty differ between Eastern and Western cultures? International Business Review, 23(1), 284-292. JOUR. https://doi.org/http://dx.doi.org/10.1016/j.ibusrev.2013.05.002

Zhang, S., van Doorn, J., \& Leeflang. P. S. H. (2014). Does the Importance of Value, Brand and Relationship Equity for Customer Loyalty Differ between Eastern and Western Cultures?. International Business Review 23(1), $284-92$. http://linkinghub.elsevier.com/retrieve/pii/S0969593113000711 (March 6, 2017).

The article has been reviewed.

Received in March, 2017; accepted in April, 2018. 